OPEN ACCESS

Edited by:

Marta Catalfamo,

Georgetown University Medical

Center, United States

Reviewed by:

Vanessa Figliuolo da Paz,

University of Arizona, United States

Luiz Eduardo Baggio Savio,

Federal University of Rio

de Janeiro, Brazil

*Correspondence:

Davide Ferrari

davide.ferrari@unife.it

Fabio Casciano

fabio.casciano@unife.it

Specialty section: This article was submitted to Inflammation,

a section of the journal

Frontiers in Immunology

Received: 15 October 2020 Accepted: 21 December 2020 Published: 16 February 2021

Citation:

Ferrari D, la Sala A, Milani D, Celeghini $C$ and Casciano F (2021)

Purinergic Signaling in Controlling Macrophage and T Cell Functions During Atherosclerosis Development.

Front. Immunol. 11:617804. doi: 10.3389/fimmu.2020.617804

\section{Purinergic Signaling in Controlling Macrophage and T Cell Functions During Atherosclerosis Development}

\author{
Davide Ferrari $^{1 *}$, Andrea la Sala ${ }^{2}$, Daniela Milani $^{3}$, Claudio Celeghini ${ }^{3}$ \\ and Fabio Casciano ${ }^{3 *}$ \\ ${ }^{1}$ Department of Life Science and Biotechnology, Section of Microbiology and Applied Pathology, University of Ferrara, \\ Ferrara, Italy, ${ }^{2}$ Certification Unit, Health Directorate, Bambino Gesù Pediatric Hospital, IRCCS, Rome, Italy, ${ }^{3}$ Department of \\ Translational Medicine and LTTA Centre, University of Ferrara, Ferrara, Italy
}

Atherosclerosis is a hardening and narrowing of arteries causing a reduction of blood flow. It is a leading cause of death in industrialized countries as it causes heart attacks, strokes, and peripheral vascular disease. Pathogenesis of the atherosclerotic lesion (atheroma) relies on the accumulation of cholesterol-containing low-density lipoproteins (LDL) and on changes of artery endothelium that becomes adhesive for monocytes and lymphocytes. Immunomediated inflammatory response stimulated by lipoprotein oxidation, cytokine secretion and release of pro-inflammatory mediators, worsens the pathological context by amplifying tissue damage to the arterial lining and increasing flow-limiting stenosis. Formation of thrombi upon rupture of the endothelium and the fibrous cup may also occur, triggering thrombosis often threatening the patient's life. Purinergic signaling, i.e., cell responses induced by stimulation of P2 and P1 membrane receptors for the extracellular nucleotides (ATP, ADP, UTP, and UDP) and nucleosides (adenosine), has been implicated in modulating the immunological response in atherosclerotic cardiovascular disease. In this review we will describe advancements in the understanding of purinergic modulation of the two main immune cells involved in atherogenesis, i.e., monocytes/macrophages and $\mathrm{T}$ lymphocytes, highlighting modulation of pro- and anti-atherosclerotic mediated responses of purinergic signaling in these cells and providing new insights to point out their potential clinical significance.

\section{Keywords: T lymphocytes, extracellular ATP and adenosine, CD39 and CD73, P1 and P2 receptors, atherosclerosis,} macrophage, necrotic core, oxLDL

\footnotetext{
Abbreviations: AC, adenylate cyclase; ADO, adenosine; ADP, adenosine diphosphate; $\mathrm{ATP}$, adenosine diphosphate; $\mathrm{CKD}$, chronic kidney disease; DAMPs, damage-associated molecular patterns; DC, dendritic cells; GM-CFS, granulocytemacrophage colony-stimulating factor; ICAM-1, intercellular adhesion molecule 1; IFN, interferon; IL, interleukin; LDL, low-density lipoproteins; LPS, lipopolysaccharides; MCP-1, monocyte chemoattractant protein-1; MMP9, Matrix Metallopeptidase 9; NLRP3, NACHT, LRR and PYD domains-containing protein 3; NO, nitric oxide; NTPDase, ectonucleoside triphosphate diphosphohydrolase; oxLDL, oxidized low-density lipoprotein; PAMPs, pathogen-associated molecular pattern; ROI, reactive oxygen intermediates; ROS, reactive oxygen species; SLE, systemic lupus erythematosus; SMC, smooth muscle cells; TGF- $\beta$, transforming growth factor $\beta$; TLR, toll-like receptors; TNF- $\alpha$, tumor necrosis factor $\alpha$; UDP, uridine diphosphate; UTP, uridine triphosphate; VCAM-1, vascular cell adhesion protein 1.
} 


\section{INTRODUCTION}

Atherosclerosis is a chronic inflammatory disease of the arteries, characterized by the development of characteristic lesions named atheromatous plaques $(1,2)$. It represents the most diffuse pathological state of peripheral and coronary artery disease, as well as of cerebrovascular disorders (3). Factors participating in the atherosclerotic process have been identified, among them: genetic predisposition, hyperlipidemia, metabolic dysregulation (obesity, diabetes), hypertension and smoking (4). A role for microorganisms has also been hypothesized, at least for the initial stages of atherosclerosis (Figure 1, topic 1) (5-8). The first steps of atherogenesis are characterized by endothelium activation and changes in lipid permeability. Expression of VCAM-1, ICAM-1, P-Selectin and different cytokine receptors allows endothelial adhesion of immune cells (monocytes, lymphocytes, neutrophils) (9). Permeation of cholesterolcontaining low-density lipoproteins (LDL) in the inner lining of the artery wall and their oxidation (oxLDL) by reactive oxygen species (ROS) favor leukocyte activation and amplification of the pro-inflammatory background (Figure 1, topic 2) (1). Upon expression of scavenger receptors, engulfment of oxLDL and migration to the intima, circulating monocytes become macrophages (foam cells) that dying in the plaque release engulfed lipids (Figure 1, topics 3, 4). Necrotic immune cells, debris, extracellular lipids and cholesterol crystals are not cleared efficiently and accumulate within the plaque-forming the socalled "necrotic core" (Figure 1, topics 5, 8-9) (2).

Macrophages are central in atherosclerosis as they participate in all stages of atheroma formation (10-12). Circulating monocytes are captured by the activated endothelium and undergo differentiation into macrophages and changing their phenotype according to stages of the atherosclerotic process. They perform different tasks ranging from perception of danger signals, engulfment of lipids and dead cells, secretion of inflammatory (ROS, activating cytokines) but also proresolving molecules (12). Atheromas are mainly populated by pro-inflammatory M1 macrophages but also by DC able to perform antigen presentation to $\mathrm{T}$ lymphocytes $(13,14)$. Interestingly, while M1 macrophages promote atherogenesis, M2 are atheroprotective (15). Macrophages are activated by the Thl cytokine IFN- $\gamma$ to produce ROI and NO (Figure 1). IFN- $\gamma$ is fundamental for the pathogenesis of atherosclerosis and endowed with the ability to cause atheroma even in the absence of immune cells $(16,17)$. Adaptive immunity takes part in the pathogenesis of atherosclerosis $(18,19)$. Although monocytes migrating through the intima are more abundant than $\mathrm{T}$ lymphocytes, these latter cells are crucial for the formation of the lesion as they produce activation signals for macrophages thus amplifying their contribution to atheroma formation (20). Differentiation of naïve $\mathrm{CD} 4^{+}$lymphocytes to effector and memory $\mathrm{T}$ cell subsets take place during atherogenesis (21). Antigen presentation by lesional macrophages and DC enables $\mathrm{T}$ cells to recognize antigens promoting the pro-inflammatory response underlying atherosclerosis (Figure 1, topic 10). Among them: LDL, oxLDL, beta 2 microglobulins, HSP60, and apo B-100 $(22,23)$. $\mathrm{T}$ cell polarization into Th1 and Th17 populations induce production of TNF- $\alpha$, IL-17a and IFN- $\gamma$ pro-inflammatory cytokines $(16,24,25)$; however, Treg antiinflammatory IL-10 and TGF- $\beta$ cytokines have also been detected in the atheromatous lesions (23). Therefore, $\mathrm{T}$ cells secrete pro- and anti-inflammatory cytokines that direct evolution and stability of the plaque $(19,26)$.

Fibroblasts proliferate and secrete collagen, proteoglycans and elastin that accumulate in the intima (Figure 1, topic 11) (27). Immune cells promote not only atheroma formation but also its evolution with complications, damage, and sometimes disruption $(23,28)$. Thrombotic complications may also occur as a consequence of endothelial damage, rupture of the fibrous cap and exposure of prothrombotic material which triggers platelet activation and lead to blood coagulation. Plaque fracture is a very dangerous event threatening patients' life. It is highly dependent on the plaque composition as it is more frequent in atheromas rich in macrophages and poor of fibroblasts and consequently in collagen fibers (29). However, plaque destabilization and rupture is still an unpredictable event and strategies to stabilize the lesion represent a challenging problem.

In the present review, we will illustrate the importance of purinergic signaling in modulating pro- and anti-atherogenic responses, particularly in $\mathrm{T}$ cells and macrophages. We will also highlight the potential of purinergic receptor agonists and antagonists for new therapeutic strategies to treat atherosclerosis.

\section{PATHOGENESIS OF ATHEROSCLEROSIS}

Although abnormal lipid accumulation in the artery wall during atheroma formation is considered the main hallmark of the disease (30), there is still debate on triggering factors and stressors taking part in the initial stages of the disease. While there is a consensus on the participation of innate and adaptive immunity in chronic inflammation underlying atherogenesis, less is known on signals activating immune cells. Danger signals, i.e., pathogen-associated molecular patterns (PAMPs) derived from viruses and bacteria, as well as danger-associated molecular patterns (DAMPs), which are intracellular or endogenous molecules, have been linked to atherosclerosis (31). Among PAMPs, bacterial lipopolysaccharide (LPS), cytomegalovirus (CMV) and human immunodeficiency virus (HIV); while among DAMPs indicated to take part in atherogenesis: minimally modified LDL, oxidized LDL, oxidized phospholipids, advanced glycation end-products, high-mobility group box 1 and heat shock proteins. Interestingly, fatty acids can induce sterile vascular inflammation (Figure 1, topic 1) (32).

Cytokines play a fundamental role in atherosclerosis and associated comorbidities (e.g. psoriasis, SLE, CKD) (33-37). Pro- and anti-atherogenic cytokines have been shown. To the first group belong molecules with pro-inflammatory activities, such as interferons (IFNs) $(\alpha, \beta, \gamma)$, interleukin-(IL) $1 \beta$, IL-6, IL-17a, granulocyte-macrophage colony-stimulating factor (GM-CSF), monocyte chemoattractant protein-1 (MCP-1), tumor necrosis factor (TNF)- $\alpha$ while among anti-atherogenic cytokines, transforming growth factor (TGF)- $\beta$, IL-10, and IL- 35 . The preeminent effect of pro-atherogenic cytokines ranges from 


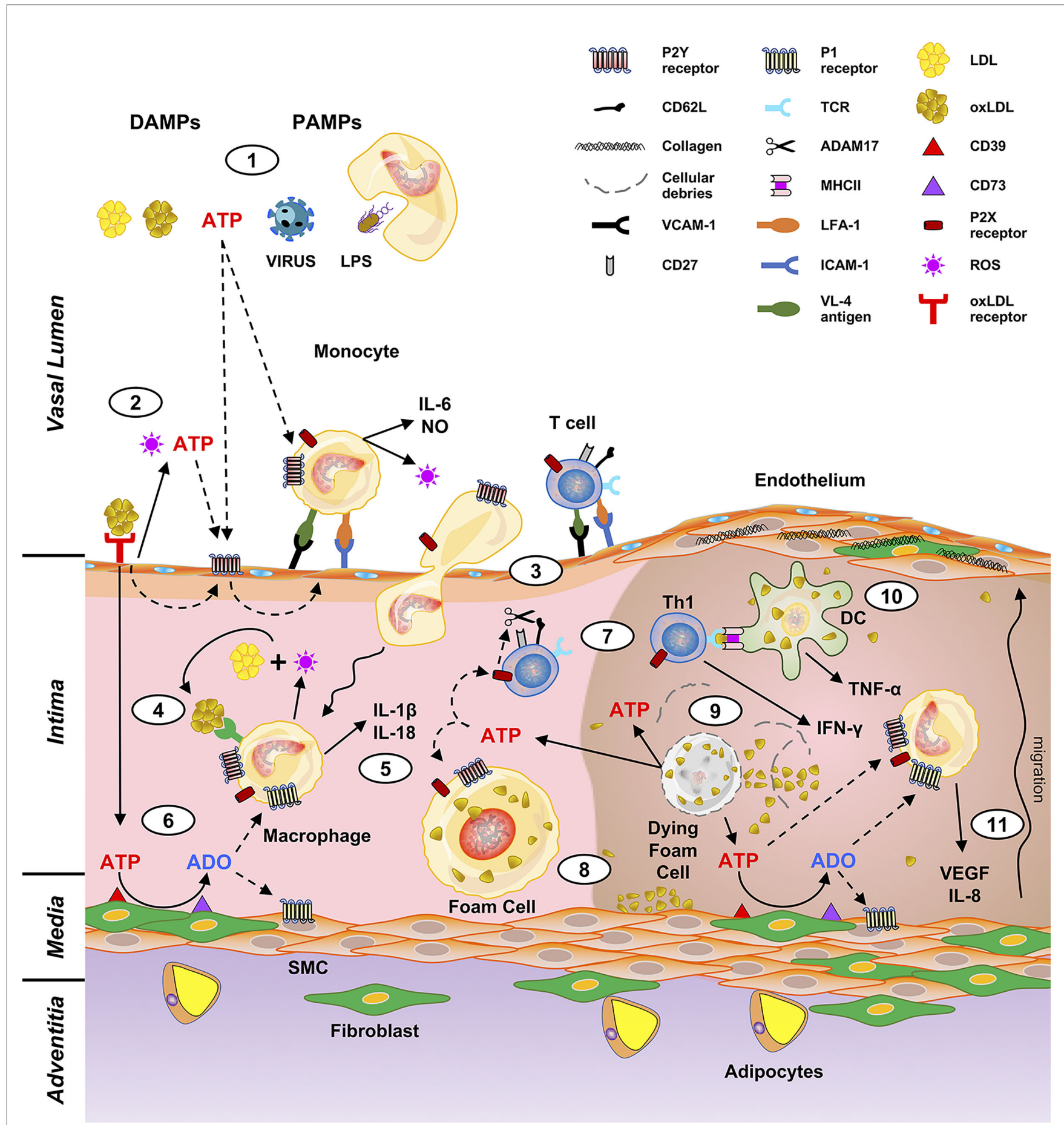

FIGURE 1 | Putative role of purinergic signaling in driving macrophages and T cell activation in atheroma development. DAMPs (LDL, oxLDL, extracellular ATP) and PAMPs (viruses, microbes, LPS) trigger the production of cytokines and oxygen species by monocytes (1). This induces release of ATP from the endothelial cells and expression of the leukocyte adhesion molecules (vascular cell adhesion molecule 1, VCAM-1; intercellular adhesion molecule 1, ICAM-1) (2) thus prompting adhesion and extravasation of monocytes and lymphocytes (3). Macrophage derived ROS oxidate LDL to oxLDL (4) and stimulate IL-1 13 and IL-18 production (5). Extracellular ATP is also converted to ADO by CD39 and CD73, which are expressed by the intima cells (6). ADO exerts a down-modulation of the immune response therefore has a protective effect. On the contrary, ATP acts as a proinflammatory molecule inducing the cleavage of CD62L by ADAM17 and T cell polarization to a Th1 phenotype (7). Upon engulfment of oxLDL, macrophages become foam cells (8). The atheroma "necrotic core" (right part of the figure) forms by accumulation of dying foam cells, lipids, cholesterol crystals and immune cells (9). Pro-inflammatory IFN- $\gamma$ and TNF- $\alpha$ are released upon antigen presentation to T lymphocytes by DC (10), and in turn promote IL-8 and VEGF secretion, with consequent fibroblasts and SMC migration and proliferation (11). 
induction of the synthesis of other cytokines, amplifying the proinflammatory activities of immune cells, to upregulation of endothelial adhesion molecules, thus favoring attachment and diapedesis of monocytes and lymphocytes (38).

\section{PURINERGIC RECEPTORS}

Nucleotides and nucleosides are not just accumulated and used within the cell but they are also secreted and synthesized extracellularly where they serve as intercellular messengers. ATP, ADP, UTP, UDP and adenosine, just to cite some, present at high concentrations within the cell where they exert multiple roles, bind extracellularly to evolutionary conserved P2 (activated by nucleotides) and P1 (activated by adenosine) plasma membrane receptors (Figure 2). Signal transduction of these receptors modulates cell and tissue pathways involved in tissue metabolism, gastrointestinal and hepatic function, circulation, nervous tissue response and immune defense (39-41). Interestingly, dysregulation of the purinergic signaling network has been implicated in the pathogenesis of allergic and neurological diseases, tissue fibrosis and cancer (42-46). Extracellular nucleotides participate in normal circulation physiology, but also in the onset of pathologic states that develop into the blood vessels, such as in blood hypercoagulability, thrombosis, atherosclerosis $(40,47,48)$.

\section{P2 Receptors P2X Receptors}

They are grouped into two subfamilies, namely: P2X and P2Y (49) (Figure 2). P2X receptors comprise seven subtypes (P2X1$\mathrm{P} 2 \mathrm{X7}$ ). They are highly conserved, trimeric, ATP-gated ion channels, selective for monovalent and divalent cations $\mathrm{Na}^{+}$, $\mathrm{K}^{+}, \mathrm{Ca}^{2+}, \mathrm{Mg}^{2+}$. Upon binding of the ligand, some of them desensitize $(50,51)$. Interestingly, the existence of lipid rafts and the level of cell membrane cholesterol can modulate the sensitivity of P2X receptors to ATP $(52,53)$. For the many responses they mediate in the circulatory apparatus, P2X receptors have been chosen as therapeutic targets for the cardiovascular system $(54,55)$.

The seventh subtype is an exception between P2X for its permeability transition and for not desensitizing in the presence of ATP (56). Its potential interest in atherogenesis is very high. Involvement of P2X7 in energy metabolism has been shown in mice; accordingly, deletion of the receptor induces lipid accumulation, fat mass distribution increase and gain of weight

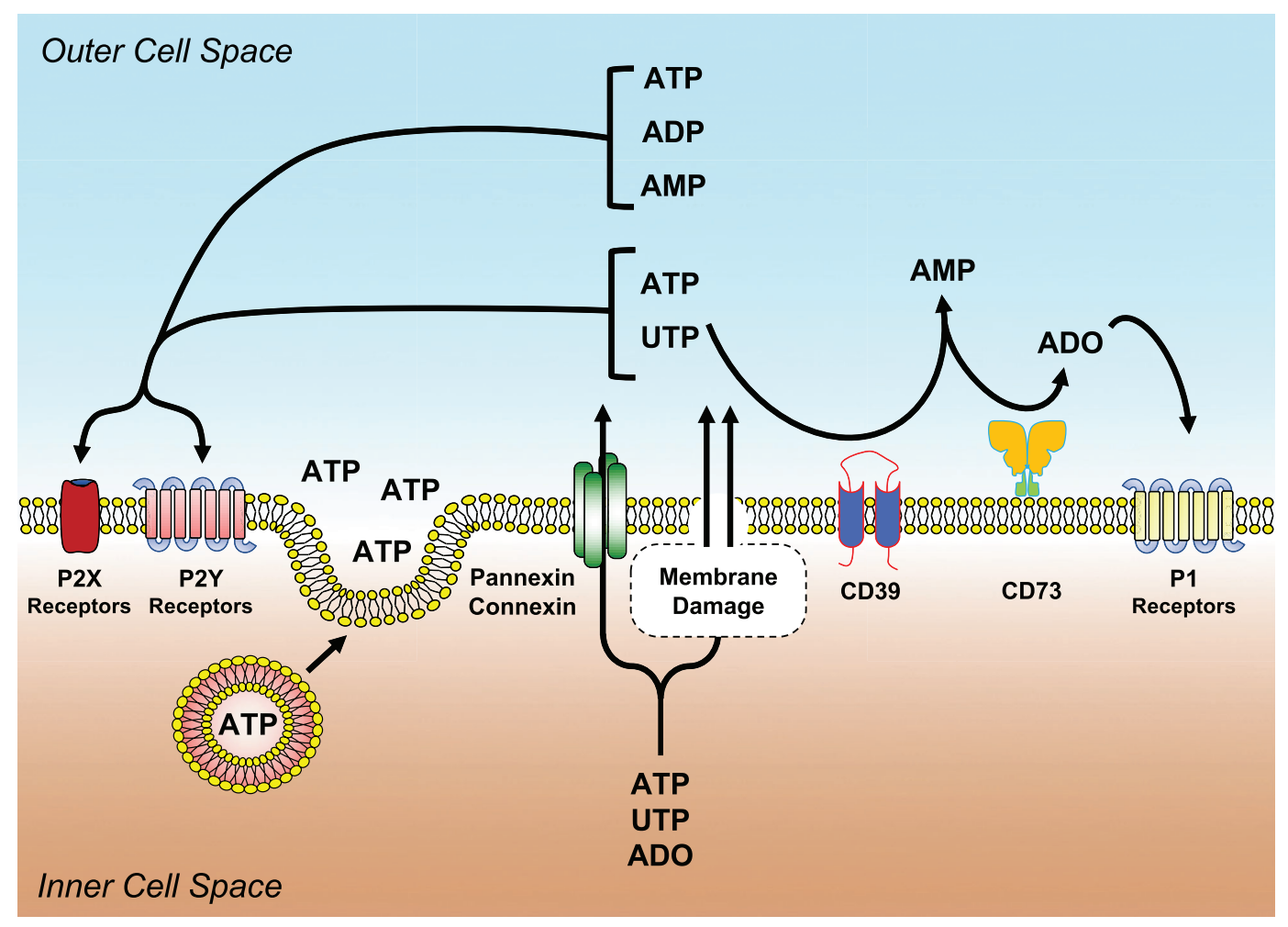

FIGURE 2 | Main molecular components of the purinergic signaling network. Nucleotides (ATP, ADP, UTP, UDP, etc.) and nucleosides (ADO) can be released or transported extracellularly as a consequence of shear stress membrane damage, hypoxia, apoptosis, necrosis and infections. Once liberated, they bind and activate purinergic $\mathrm{P} 2(\mathrm{P} 2 \mathrm{Y}$ and $\mathrm{P} 2 \mathrm{X})$ or $\mathrm{P} 1\left(\mathrm{~A}_{1}, \mathrm{~A}_{2 \mathrm{~A}}, \mathrm{~A}_{2 \mathrm{~B}}, \mathrm{~A}_{3}\right)$ receptors. ADO is generated from the enzymatic conversion of $\mathrm{ATP} / \mathrm{ADP}$ to $\mathrm{AMP}$ by the ectonucleoside triphosphate diphosphohydrolase CD39 and with the hydrolysis of AMP to ADO by the ecto-5'-nucleotidase CD73. ADO activates P1 receptors. 
(57). The receptor is also endowed with the ability to induce transcription and secretion of inflammatory cytokines such as IL-1 $\beta$, IL-18 (Figure 1, topic 5) and IL-6 which are central in atherosclerosis (58-60). Hence, Toll-like receptors (TLR) and P2 purinergic receptors induce activation of inflammasomes (61). Their activation by extracellular ATP causes IL-1 $\beta$ and IL-18 release (62). Interestingly, engulfment of lipids by macrophages increases the sensitivity of TLR to their ligands and activates NLRP3 (also known as NOD-, LRR- and pyrin domaincontaining 3, NALP3) inflammasome $(63,64)$. NLRP3 is activated by two signals: the first being microorganisms or inflammatory cytokines endowed of the ability to activate transcription factor NF- $\kappa \mathrm{B}$, upregulate NLRP3 proteins and expression of the inactive form of the cytokines; while the second step is mediated by different stimuli among which extracellular ATP through activation of the P2X7 receptor (65). An important confirmation on the importance of P2X7 in atherogenesis comes from the animal model, where the absence of this subtype inhibits inflammasome activation and improves atherosclerosis (66).

\section{P2Y Receptors}

$\mathrm{P} 2 \mathrm{Y}$ receptors include eight subtypes named: $\mathrm{P} 2 \mathrm{Y}_{1}, \mathrm{P}_{2} \mathrm{Y}_{2}, \mathrm{P}_{2} \mathrm{Y}_{4}$, $\mathrm{P}_{2} \mathrm{Y}_{6}, \mathrm{P} 2 \mathrm{Y}_{11}, \mathrm{P} 2 \mathrm{Y}_{12}, \mathrm{P} 2 \mathrm{Y}_{13}$ and $\mathrm{P}_{2} \mathrm{Y}_{14}$ (67). They have a membrane topology with seven-transmembrane domains and couple intracellularly to $\mathrm{G}_{\mathrm{q}} / \mathrm{G}_{11}$ or $\mathrm{G}_{\mathrm{i} / 0}$ proteins (67) (Figure 2). They differ in agonist specificity. $\mathrm{P}_{2} \mathrm{Y}_{1}, \mathrm{P}_{2} \mathrm{Y}_{12}$ and $\mathrm{P} 2 \mathrm{Y}_{13}$ subtypes are preferentially activated by ADP (68), whereas $\mathrm{P} \mathrm{Y}_{6}$ by UDP. P2 $\mathrm{Y}_{2}$ is activated by UTP or ATP, while $\mathrm{P}_{4} \mathrm{Y}_{4}$ and $\mathrm{P}_{2} \mathrm{Y}_{11}$ are selective for UTP and ATP, respectively (69). $\mathrm{P} \mathrm{Y}_{14}$ is activated by UDP-glucose (69). P2Y receptors modulate several physiological responses.

Endotheliocytes release ATP in response to blood flow changes, hypoxia, or damaging agents $(40,70,71)$. Moreover, ATP and other nucleotides are released from all dying cells and act as DAMPs activating and recruiting immune cells (58) (Figures 1 and 2). Interestingly, oxLDL favor nucleotide release from endothelial cells (72). Triggering of the $\mathrm{P}_{2} \mathrm{Y}_{2}$ receptor by ATP secreted by endothelial cells upon stimulation with oxLDL induces expression of receptors for advanced glycation end-products and adhesion molecules (73). Furthermore, the release of ROS and ATP/UDP from endothelial cells upon exposure to oxidized low-density lipoprotein (oxLDL), induce autocrine $\mathrm{P}_{2} \mathrm{Y}_{1}$-mediated upregulation of ICAM-1 and VCAM-1 with subsequent stimulation of leukocyte adhesion (74) (Figure 1, topic 2).

As an example, platelet aggregation is dependent on adenosine $\mathrm{ADP} / \mathrm{P} 2 \mathrm{Y}_{12}$-mediated amplification of thrombin effects. During platelet aggregation, the $\mathrm{ADP}$ receptor $\mathrm{P}_{2} \mathrm{Y}_{12}$ plays a pivotal procoagulant role as shown by the benefits gained by its inhibition with the receptor blocker Clopidogrel in patients with cardiovascular disease such as in acute coronary syndrome, recent stroke and arterial disease $(75,76)$. In abdominal aortic aneurysm, a condition characterized by dilatation of the abdominal aorta which involves antigen-driven $\mathrm{T}$ cells in the site of inflammation (77), Clopidogrel reduces the content of cytotoxic CD8 ${ }^{+} \mathrm{T}$ cells in the aortic wall and has an ameliorative role in the disease (78).
Indeed, P2Y receptors would be central in inducing endothelium activation and atherogenic modifications at least in the double negative knockout $\left(\mathrm{P}_{2} \mathrm{Y}_{1}{ }^{-/-} / \mathrm{ApoE}^{-/-}\right)$mice. In these animals, the $\mathrm{P}_{2} \mathrm{Y}_{1}$ subtype contributes to TNF- $\alpha$-induced ICAM-1 and VCAM-1 exposure with consequent leucocyte recruitment in inflamed femoral arteries (79). Moreover, reduction of the aortic sinus lesions associated to a decrease in macrophages infiltration and to a diminished VCAM-1 expression in endothelial cells of $\mathrm{P} 2 \mathrm{Y}^{-/-} \mathrm{ApoE}^{-/-}$compared to $\mathrm{ApoE}^{-/-}$mice suggests that atherosclerotic lesions are due to endothelial or smooth muscle cells expression of $\mathrm{P}_{2} \mathrm{Y}_{1}$ receptors (80). Interestingly, bacterial lipopolysaccharide (LPS) upregulates lectin-like oxLDL receptor in endothelial cells (81), which in turn induces a $\mathrm{P}_{2} \mathrm{Y}_{1^{-}}$and $\mathrm{P}_{2} \mathrm{Y}_{1}$-mediated upregulation of ICAM-1 and VCAM-. This prompts leucocyte adhesion to endothelial cells (74). Similarly, the $\mathrm{P}_{2} \mathrm{Y}_{2}$ subtype promotes atherosclerosis in mice by inducing the expression of the same adhesion molecules. Matrix metalloproteinase- 2 proteolytic activity was reduced in atheroma of $\mathrm{P} 2 \mathrm{Y}_{2}^{-/-} \mathrm{ApoE}^{-/-}$mice (82). Another potentially very interesting for the pathogenesis of atherosclerosis is the $\mathrm{P}_{2} \mathrm{Y}_{6}$ subtype. Hence, $\mathrm{P}_{2} \mathrm{Y}_{6}$ is upregulated during vascular inflammation induced by TNF- $\alpha$ or LPS stimulation in mice, and its inhibition or ablation reduces the vascular inflammatory response (83). These findings suggest that $\mathrm{P} 2 \mathrm{Y}$ receptors could be targeted for therapeutic purposes in atherosclerosis.

\section{P1 Receptors}

$\mathrm{P} 1$ receptors are activated by adenosine $(\mathrm{ADO})$ that can be transported outside the cell by specific membrane transporters or generated extracellularly by ATP and ADP hydrolysis (see next paragraph) (Figure 1). ADO concentration in the extracellular fluids ranges from 100 to $500 \mathrm{nM}$ in homeostatic conditions while it augments to low micromolar for the presence of inflammation or during hypoxia and ischemia $(84,85)$.

ADO or ADORA receptors consist of four subtypes: $A_{1}$ (ADORA1), $\mathrm{A}_{2 \mathrm{~A}}$ (ADORA2A), $\mathrm{A}_{2 \mathrm{~B}}$ (ADORA2B) and $\mathrm{A}_{3}$ (ADORA3). They are seven-transmembrane G-protein-coupled receptors that associate with $\mathrm{G}$-proteins. Depending on receptor subtype, $A D O$ activates $\left(A_{2 A}, A_{2 B}\right)$ or inhibits $\left(A_{1}, A_{3}\right)$ adenylate cyclase (AC) (86). ADORA receptors also differ in ligand affinity, being $A_{1}, A_{2 A}$ and $A_{3}$ subtypes activated by low (10-50 nM) ADO concentrations while on the contrary, $A_{2 B}$ needs around 1 $\mathrm{mM}$ ADO for activation (87).

$\mathrm{P} 1$ receptors induce multiple responses $(42,85,88)$. Extracellular ADO is very important to dampen acute inflammation thus preventing tissue injury. ADO-mediated immunosuppressive mechanisms are mainly based on inhibition of pro-inflammatory cytokine secretion, production of suppressive cytokines and induction of regulatory immune cells. Endothelial cells use adenosinergic signaling to regulate the leakiness through the endothelial monolayer of the brain capillaries, for the passive exchange of solutes and proteins (89, 90); however, the use of P1 agonists, particularly of the $A_{2 A}$ subtype has to be carefully evaluated for the side effects deriving from the $\mathrm{T}$ cell migration through the blood-brain barrier (91). Interestingly, $\mathrm{A}_{2 \mathrm{~A}}$ receptor signaling has also been indicated as a target for limiting aneurysm formation (92); $A_{3}$ antagonism 
reduces hypercholesterolemia in $\mathrm{ApoE}^{-/-}$mice (93). Therefore, $\mathrm{ADO}$ and its receptors represent promising pharmacological targets to treat atherosclerosis.

\section{Ectonucleotidases}

Extracellular nucleotide concentration in homeostatic conditions is low or close to zero. This is due to the hydrolyzing activity of different plasma membrane ectonucleotidases transforming ATP to ADP and then to ADO (Figure 2). Besides avoiding of accumulation of nucleotides in the extracellular milieu, these enzymes degrade $\mathrm{P} 2$ receptor agonists (i.e., nucleotides) lowering their concentration thus reducing the efficiency of stimulation. Conversely, their activity augments the amount of ADO thus increasing the probability of activating P1 receptors (42). Shifting from P2 to P1 activation has quite often the consequence of changing purinergic-mediated responses from pro- to antiinflammatory, thus preserving tissue integrity (94).

Different ectonucleotidase families have been described: ectonucleotide pyrophosphatase/phosphodiesterase (NPP), alkaline phosphatases, ectonucleoside triphosphate diphosphohydrolases (NTPDases, among which CD39 or NTPDase1) and ecto-5'nucleotidase (CD73). CD39 catalyzes the conversion of ATP or ADP to AMP, while CD73 hydrolyzes AMP to ADO (95-97) (Figure 2). Ectonucleotidases play a central role in immune regulation, thus preventing the development of conditions favoring autoimmune diseases (94). Moreover, the generation of $\mathrm{ADO}$ by ectonucleotidases reduces tissue damage and ameliorates tissue physiology in hypoxia-related disease states $(98,99)$. CD39 has been associated with resistance to thrombus formation in injured mice arteries (100) while in $\mathrm{CD}^{-/-}$mice, absence of the enzyme does not directly affect thrombosis, but indirectly lowers it by increasing CD39 expression, particularly on monocytes $(101,102)$. CD39 likely exerts multiple and sometimes apparently contrasting effects in atherosclerosis. The absence of this gene in hyperlipidemic mice decreases atheroma formation and it was hypothesized that this effect resulted from multiple contributions, i.e.: decreased platelet activation, increased plasma HDL concentration and augmented cholesterol efflux (103). Expression of CD39 is crucial in neointimal formation after vascular injury in mice as its absence impairs the migration of vascular smooth muscle cells (104).

\section{MODULATION OF MACROPHAGES BY PURINERGIC SIGNALING DURING ATHEROGENESIS}

\section{P2 Mediated Effects}

Macrophages and DC express both $\mathrm{P} 2 \mathrm{X}$ and $\mathrm{P} 2 \mathrm{Y}$ receptor subtypes that are involved in modulating responses ranging from cytokine secretion, giant cell formation, production of oxygen radicals and antigen presentation.

Immunohistochemistry demonstrates that $\mathrm{P}_{2} \mathrm{Y}_{6}$ is upregulated in the atherosclerotic aortic segment of $\mathrm{ApoE}^{-/-}$ mice after 4 -week of cholesterol-enriched diet, with the accumulation of $\mathrm{P}_{2} \mathrm{Y}_{6}$ expressing macrophages into the plaque. Interestingly, Suramin or PPADS treatments were able to reduce the plaque size, without modification of the number of macrophages and smooth muscle cells (105). $\mathrm{P}^{2} \mathrm{Y}_{6}$ receptor mRNA increases in aortic portions with atherosclerosis, while expression of the mRNA for other P2Y subtypes (P2Y1, P2Y, $\mathrm{P}_{2} \mathrm{Y}_{4}$ ) remain unchanged (105). However, the participation of the $\mathrm{P}_{2} \mathrm{Y}_{6}$ receptor to atherosclerosis in mice seems to be dependent on the experimental model used. A reduction in atherosclerotic plaque formation in the aortic arch was observed in high fat-fed LDLR knockout mice lacking the $\mathrm{P}_{2} \mathrm{Y}_{6}$ receptor in bone marrow-derived cells, but not in other mouse models (106). P2X7 is highly expressed in immune cells, particularly in macrophages where it is involved in IL-1 $\beta$ and IL-18 processing and release $(59,107-110)$. Macrophages are the main source of IL-1 $\beta$, which is responsible for inflammation linked to atherosclerosis. It can thus be hypothesized that stimulation of P2X7 by extracellular ATP released within the atheroma induces the release of this pro-inflammatory cytokine (111-113). The efficacy of the A740003, a P2X7 specific antagonist, in decreasing vessel inflammation further supports its role in atherosclerosis and gives a new chance for the local pharmacological targeting of atherosclerosis (113).

IFN- $\gamma$ is also a central mediator in atherosclerosis (114). IFN- $\gamma$ potentiates IL-1 $\beta$ release from primary human monocyte-derived DC. Indeed, IFN- $\gamma$ also upregulates expression of the P2X7 subtype, which in turn prompts IL-1 $\beta$ secretion $(115,116)$. IL18 and its functional receptor have been detected in human endothelial cells, SMC and macrophages, and are implicated in atherogenesis (117). Since P2X7 expressed by human macrophages is also involved in ATP stimulated IL-18 release it again represents a suitable candidate for pharmacological targeting of atherosclerosis (108).

The centrality of NLRP3 inflammasome in atherosclerosis has also been well ascertained (118). Different approaches have been successfully attempted to inhibit the protein complex both in vitro and in vivo. This latter has shown a positive effect on experimentally induced atherosclerosis (119121). Extracellular ATP is among stimuli that potently activate NLRP3, therefore, it is very promising for therapeutic purposes the observation that deficiency of a single purinergic receptor, namely the P2X7 subtype, is sufficient to block NLRP3 inflammasome and ameliorate the clinical picture of atherosclerosis in mice (122).

\section{MODULATION OF T LYMPHOCYTES BY PURINERGIC SIGNALING DURING ATHEROGENESIS}

\section{P2 Mediated Effects}

$\mathrm{P} 2 \mathrm{Y}$ and $\mathrm{P} 2 \mathrm{X}$ receptor activation lead the inflammatory processes of the vessels favoring interactions between leukocytes, platelets and vessel wall. The $\mathrm{P}_{2} \mathrm{Y}_{12}$ subtype has attracted interest for its pro-thrombotic and pro-inflammatory 
role both in Apolipoprotein E-deficient mice and in humans (123). Contribution of the ADP receptor in modulating atherogenesis in the mouse model would be at least in part due to the induction of platelet $\alpha$-granule release that would increase recruitment of inflammatory cells (124).

During atheroma formation, platelets induce a phenotype change and INF- $\gamma$ secretion in human $\mathrm{CD}^{+} \mathrm{T}$ lymphocytes; but administration of the $\mathrm{P}_{2} \mathrm{Y}_{12}$ receptor blocker Prasugrel to human volunteers completely inhibits platelet-mediated pro-inflammatory changes induced in Th cells. Therefore, anticoagulant therapy with Prasugrel may provide therapeutic benefits both from direct platelet inhibition and also by downregulating the immune response (125). Clopidogrel, another $\mathrm{P}_{2} \mathrm{Y}_{12}$ inhibitor decreases expression of the purinergic receptor by leukocytes, ameliorates atheroma conditions and stabilizes aortic sinus plaques increasing the number of atheroprotective regulatory $\mathrm{CD} 4{ }^{+} \mathrm{CD} 25^{+} \mathrm{T}$ (Treg) cells in $\mathrm{ApoE}^{-/-}$mice $(126,127)$. Although atherosclerosis is characterized by migration of different immune cells through the vessel wall, at least in the mouse model, lymphocytes are already present within the normal/noninflamed aorta before the onset of atheroma; while macrophages and DC that perform $\mathrm{T}$ cell antigen presentation are recruited into the artery wall. This migration is partially dependent on L-selectin (CD62L) both in normal and atherosclerosis-prone $\mathrm{ApoE}^{-/-}$mouse aorta (128). Shedding of CD62L occurs during lymphocyte activation and rolling; interestingly, activation of the $\mathrm{P} 2 \mathrm{X} 7$ receptor triggers the shedding of CD62L in leukocytes (Figure 1, topic 7) $(129,130)$.

\section{P1 Mediated Effects}

It is long known that ADO has anti-inflammatory properties (58). Curiously, the potent anti-inflammatory drug methotrexate is responsible for $\mathrm{ADO}$ release that activating $\mathrm{A}_{2}$ receptors expressed by immune cells, reduces their presence in the inflamed tissue (131). Since ADO acts as a downmodulator of the immune response, it exerts atheroprotective functions by reducing the secretion of pro-inflammatory cytokines, thus lowering immune-mediated tissue damage (58). The role of $\mathrm{CD}^{+} \mathrm{T}$ lymphocytes in atherosclerosis has been the object of intense debate. However, a recent report has shed light on this issue and on the involvement of CD39 ectonucleotidase in conferring a regulatory and atheroprotective phenotype to $\mathrm{CD}^{+}$cells. This is associated with a reduction in cytokine production through increased CD39 expression in both mouse and human atherosclerotic lesions (132).

\section{CONCLUSIONS}

Atherosclerosis is a leading cause of death in developed countries and it has been the target of multidisciplinary therapeutic approaches to reduce the relevant burden of life loss and health spending. Data coming from extensive epidemiological, clinical and experimental studies show that lifestyle habits are crucial to prevent atherosclerosis. Several strategies have been tested to treat the disease, among them: cholesterol-lowering agents, blood pressure reducing drugs, anti-inflammatory agents (corticosteroids, monoclonal antibodies to cytokines) and antiP-selectin antibodies (133). Indeed, no definitive answers on the efficacy of these clinical approaches have been obtained. Therefore, novel therapeutic solutions are highly required (2, $33,133)$.

ADO, for example, behaves as a down-modulator of immune cell activation as shown in many in vitro studies as well as in animal models and clinical trials. Besides anti-inflammatory properties and inhibition of cholesterol accumulation into the vessels, ADO also shows anti-thrombotic effects, thus having an atheroprotective potential sufficient to prompt clinical trials particularly involving the A2A receptor (134-137).

Macrophages and lymphocytes are central in the evolution of atherosclerosis for their ability to produce signals feeding the underlying pro-inflammatory background of the disease (19, 26, 38).

IL-1 $1 \beta$ has a pivotal role in atherosclerosis, and purinergic signaling is the main triggering way for its release. Interestingly, Losartan, an angiotensin II receptor blocker used to treat hypertension, inhibits LPS/ATP-induced IL-1 $\beta$ secretion by suppressing NLRP3 inflammasome (119). The NALP3/P2X7 tandem has a well-ascertained role in inflammation. An important result obtained in the animal model consists in the observation that the absence of the P2X7 subtype impairs lesional inflammasome activity and ameliorates the disease, pointing to the centrality of this receptor as a trigger of NLRP3 induced inflammation (122). Due to the importance of NLRP3 in atherosclerosis, different ways have been proposed for its inactivation $(120,121,138)$. Interestingly, the P2X7 antagonist A740003 also shows an effect in decreasing IL- $1 \beta$ secretion and MMP9 activity in ex-vivo cultures of atheromatic cells, independently from NLRP3 (113). Therefore, further studies are needed to shed light on the activation of this latter P2X7 dependent proinflammatory pathway.

The $\mathrm{P}_{2} \mathrm{Y}_{2}$ receptor subtype has also been endowed with proinflammatory properties in the $\mathrm{ApoE}^{-/-}$mouse model, and prothrombotic capacities in human coronary artery endothelial cells. It would therefore be worthy to pharmacologically target this receptor in the attempt of reducing inflammation and thrombosis in atherosclerosis (139). Involvement of the $\mathrm{P}_{2} \mathrm{Y}_{6}$ receptor in the inflammatory background underlying atherosclerosis has been shown both in mice and humans $(105,140)$. This subtype is expressed in murine atherosclerotic plaques and is involved in NO production and IL-6 secretion in murine macrophages (105). The P2Y6 receptor subtype plays a role in immune cell activation and recruitment to the arterial wall, most likely by inducing MCP-1 and CCR2 overexpression, accompanied by modulation of the CCL2-mediated signaling (106, 141, 142). Accordingly, leukocyte migration and lesion size induced by the $\mathrm{P}_{2} \mathrm{Y}_{6}$ agonist UDP are decreased in $\mathrm{P}_{2} \mathrm{Y}_{6} \mathrm{R}^{-1-}$ mice. Accordingly, mice deficient in both $\mathrm{P}_{2} \mathrm{Y}_{6}$ and low-density lipoprotein, LDL, 
receptor show lower atherosclerotic lesion sizes and lipid accumulation in the aorta. Recent studies on $\mathrm{P}_{2} \mathrm{Y}_{6}$ proinflammatory effects had shed light on vascular inflammation in the presence of bacterial LPS. The $\mathrm{P}_{2} \mathrm{Y}_{6}$ receptor antagonist MRS 2578 shows a positive effect in down modulating a nuclear factor $\kappa \mathrm{B}$ reporter and expression of pro-inflammatory genes in human microvascular endothelial cells in vitro (83). Moreover, inflammation and uptake of cholesterol by macrophages are lower in atheroma of $\mathrm{P}_{2} \mathrm{Y}_{6}{ }^{-1-}$ mice, candidating the subtype as a therapeutic target for atherosclerosis $(66,106,140,143)$.

$\mathrm{P}_{2} \mathrm{Y}_{12}$ receptor represents a further very promising molecule for the treatment of the disease as its inhibitor Ticagrelor reduces cardiovascular events in patients with acute coronary syndrome and decreases inflammatory endothelial activation and vascular dysfunction in $\mathrm{ApoE}^{-/-}$mice $(144,145)$. Moreover the efficacy of Prasugrel, another $\mathrm{P}_{2} \mathrm{Y}_{12}$ receptor blocker, in abolishing prothrombotic and pro-inflammatory responses of platelets and $\mathrm{CD} 4^{+} \mathrm{T}$ cells in humans, may also provide an indirect positive effect on the inflammatory response underlying the genesis of atheroma and also in cardiovascular diseases involving $\mathrm{T}$ cells (125). Concerning $\mathrm{CD}^{+} \mathrm{T}$ lymphocytes, although their identification in the atherosclerotic lesions has already been reported a few decades ago, however, both atheroprotective and pro-atherogenic roles have been proposed, depending on the animal or research model used (146). Different CD8 ${ }^{+}$ subpopulations would have a particular role in atherosclerosis. Two putatively protecting phenotypes have been identified and would be $\mathrm{MHC}$ class I-restricted $\mathrm{CD}^{+}$lymphocytes and regulatory $\mathrm{CD} 8+\mathrm{CD} 25+\mathrm{T}$ cells (146); moreover, a role has been attributed to CD39 ectonucleotidase in reducing IFN- $\gamma$ and TNF- $\alpha$ production by $\mathrm{CD}^{+}$in atherosclerotic lesions in mice (132). Another important point is that inhibition of the $A_{2 A}$ receptor reduces the formation of foam cells, making this receptor putatively interesting to inhibit lipid accumulation within the intima $(134,135)$. Another issue to be further explored is the

\section{REFERENCES}

1. Glass CK, Witztum JL. Atherosclerosis. the road ahead. Cell (2001) 104 (4):503-16. doi: 10.1016/s0092-8674(01)00238-0

2. Libby P, Ridker PM, Hansson GK. Progress and challenges in translating the biology of atherosclerosis. Nature (2011) 473(7347):317-25. doi: 10.1038/ nature 10146

3. Lozano R, Naghavi M, Foreman K, Lim S, Shibuya K, Aboyans V, et al. Global and regional mortality from 235 causes of death for 20 age groups in 1990 and 2010: a systematic analysis for the Global Burden of Disease Study 2010. Lancet (London England) (2012) 380(9859):2095-128. doi: 10.1016/ s0140-6736(12)61728-0

4. Kalanuria AA, Nyquist P, Ling G. The prevention and regression of atherosclerotic plaques: emerging treatments. Vasc Health Risk Manage (2012) 8:549-61. doi: 10.2147/vhrm.s27764

5. Hemmat N, Ebadi A, Badalzadeh R, Memar MY, Baghi HB. Viral infection and atherosclerosis. Eur J Clin Microbiol Infect Dis (2018) 37(12):2225-33. doi: 10.1007/s10096-018-3370-z

6. Mayr M, Kiechl S, Willeit J, Wick G, Xu Q. Infections, immunity, and atherosclerosis: associations of antibodies to Chlamydia pneumoniae, Helicobacter pylori, and cytomegalovirus with immune reactions to heatshock protein 60 and carotid or femoral atherosclerosis. Circulation (2000) 102(8):833-9. doi: 10.1161/01.cir.102.8.833 involvement of TLR receptors in atherosclerosis, being TLR9 a first candidate for future studies $(138,147)$. It would also be worthy to check whether the expression of TLR is modulated by nucleotides during atherosclerosis. Experiments performed in hypercholesterolemic mice showed that oxidized phospholipids are proatherogenic; therefore, it would be interesting to check whether extracellular ATP may amplify this response (148).

The attenuation of the inflammatory background of atherosclerosis would be a desirable first step to treat the disease; rapidly expanding knowledge on the effects mediated by extracellular nucleotides and nucleosides on immune and non-immune cells participating in atherosclerosis will hopefully give a new chance of introducing new therapeutic compounds to treat inflammation and therefore atherosclerosis $(93,149)$. Another challenge consists of finding new ways for the in situ delivery of anti-atherosclerotic drugs, to block atheroma progression and possibly revert it. Nano- and micro-particles could likely be a new and possibly efficient way to administer drugs directly to the atherosclerotic lesions (150).

\section{AUTHOR CONTRIBUTIONS}

$\mathrm{DF}, \mathrm{FC}$, and AL conceived the review and wrote the manuscript. FC prepared the figures. DM and CC checked and revised the manuscript. All authors contributed to the article and approved the submitted version.

\section{FUNDING}

This manuscript was supported by local funds of the University of Ferrara (2019-FAR.L-CC_002, 2020-FAR.L-CF_003, 2019FAR.L-MD_001, 2019-FAR.L-SP_001, 2020-FAR.L-SP_001).
7. Leentjens J, Bekkering S, Joosten L, Netea MG, Burgner DP, Riksen NP. Trained Innate Immunity as a Novel Mechanism Linking Infection and the Development of Atherosclerosis. Circ Res (2018) 122(5):664-9. doi: 10.1161/ CIRCRESAHA.117.312465

8. Li B, Xia Y, Hu B. Infection and atherosclerosis: TLR-dependent pathways. Cell Mol Life Sci (2020) 77(14):2751-69. doi: 10.1007/s00018020-03453-7

9. Gimbrone MAJr., Garcia-Cardena G. Endothelial Cell Dysfunction and the Pathobiology of Atherosclerosis. Circ Res (2016) 118(4):620-36 doi: 10.1161/CIRCRESAHA.115.306301

10. Legein B, Temmerman L, Biessen EA, Lutgens E. Inflammation and immune system interactions in atherosclerosis. Cell Mol Life Sci (2013) 70(20):384769. doi: 10.1007/s00018-013-1289-1

11. Chávez-Sánchez L, Espinosa-Luna JE, Chávez-Rueda K, Legorreta-Haquet MV, Montoya-Díaz E, Blanco-Favela F. Innate immune system cells in atherosclerosis. Arch Med Res (2014) 45(1):1-14. doi: 10.1016/j.arcmed. 2013.11.007

12. Tabas I, Bornfeldt KE. Macrophage Phenotype and Function in Different Stages of Atherosclerosis. Circ Res (2016) 118(4):653-67. doi: 10.1161/ circresaha.115.306256

13. Yang S, Yuan HQ, Hao YM, Ren Z, Qu SL, Liu LS, et al. Macrophage polarization in atherosclerosis. Clin Chim Acta Int J Clin Chem (2020) 501:142-6. doi: 10.1016/j.cca.2019.10.034 
14. Paulson KE, Zhu SN, Chen M, Nurmohamed S, Jongstra-Bilen J, Cybulsky MI. Resident intimal dendritic cells accumulate lipid and contribute to the initiation of atherosclerosis. Circ Res (2010) 106(2):383-90. doi: 10.1161/ circresaha.109.210781

15. Gong M, Zhuo X, Ma A. STAT6 Upregulation Promotes M2 Macrophage Polarization to Suppress Atherosclerosis. Med Sci Monit Basic Res (2017) 23:240-9. doi: 10.12659/msmbr.904014

16. Leon ML, Zuckerman SH. Gamma interferon: a central mediator in atherosclerosis. Inflammation Res (2005) 54(10):395-411. doi: 10.1007/ s00011-005-1377-2

17. Tellides G, Tereb DA, Kirkiles-Smith NC, Kim RW, Wilson JH, Schechner JS, et al. Interferon-gamma elicits arteriosclerosis in the absence of leukocytes. Nature (2000) 403(6766):207-11. doi: 10.1038/35003221

18. Robertson AK, Hansson GK. T cells in atherogenesis: for better or for worse? Arterioscler Thromb Vasc Biol (2006) 26(11):2421-32. doi: 10.1161/ 01.ATV.0000245830.29764.84

19. Andersson J, Libby P, Hansson GK. Adaptive immunity and atherosclerosis. Clin Immunol (2010) 134(1):33-46. doi: 10.1016/j.clim.2009.07.002

20. Li J, Mcardle S, Gholami A, Kimura T, Wolf D, Gerhardt T, et al. CCR5+Tbet+FoxP3+ Effector CD4 T Cells Drive Atherosclerosis. Circ Res (2016) 118 (10):1540-52. doi: 10.1161/circresaha.116.308648

21. Ammirati E, Cianflone D, Vecchio V, Banfi M, Vermi AC, De Metrio M, et al. Effector Memory $\mathrm{T}$ cells Are Associated With Atherosclerosis in Humans and Animal Models. J Am Heart Assoc (2012) 1(1):27-41. doi: 10.1161/JAHA.111.000125

22. Stemme S, Faber B, Holm J, Wiklund O, Witztum JL, Hansson GK. T lymphocytes from human atherosclerotic plaques recognize oxidized low density lipoprotein. Proc Natl Acad Sci USA (1995) 92(9):3893-7. doi: 10.1073/pnas.92.9.3893

23. Wolf D, Ley K. Immunity and inflammation in atherosclerosis. Herz (2019) 44(2):107-20. doi: 10.1007/s00059-019-4790-y

24. Buono C, Lichtman AH. Co-stimulation and plaque-antigen-specific T-cell responses in atherosclerosis. Trends Cardiovasc Med (2004) 14(4):166-72. doi: 10.1016/j.tcm.2004.03.001

25. Eid RE, Rao DA, Zhou J, Lo SF, Ranjbaran H, Gallo A, et al. Interleukin-17 and interferon-gamma are produced concomitantly by human coronary artery-infiltrating $\mathrm{T}$ cells and act synergistically on vascular smooth muscle cells. Circulation (2009) 119(10):1424-32. doi: 10.1161/circulationaha.108. 827618

26. Zeboudj L, Maitre M, Guyonnet L, Laurans L, Joffre J, Lemarie J, et al. Selective EGF-Receptor Inhibition in CD4(+) T Cells Induces Anergy and Limits Atherosclerosis. J Am Coll Cardiol (2018) 71(2):160-72. doi: 10.1016/ j.jacc.2017.10.084

27. Singh S, Torzewski M. Fibroblasts and Their Pathological Functions in the Fibrosis of Aortic Valve Sclerosis and Atherosclerosis. Biomolecules (2019) 9 (9):472. doi: 10.3390/biom 9090472

28. Gistera A, Hansson GK. The immunology of atherosclerosis. Nat Rev Nephrol (2017) 13(6):368-80. doi: 10.1038/nrneph.2017.51

29. Libby P, Okamoto Y, Rocha VZ, Folco E. Inflammation in atherosclerosis: transition from theory to practice. Circ J (2010) 74(2):213-20. doi: 10.1253/ circj.cj-09-0706

30. Ference BA. Causal Effect of Lipids and Lipoproteins on Atherosclerosis: Lessons from Genomic Studies. Cardiol Clinics (2018) 36(2):203-11. doi: 10.1016/j.ccl.2017.12.001

31. Zimmer S, Grebe A, Latz E. Danger signaling in atherosclerosis. Circ Res (2015) 116(2):323-40. doi: 10.1161/circresaha.116.301135

32. Freigang S, Ampenberger F, Weiss A, Kanneganti TD, Iwakura Y, Hersberger M, et al. Fatty acid-induced mitochondrial uncoupling elicits inflammasome-independent IL-1alpha and sterile vascular inflammation in atherosclerosis. Nat Immunol (2013) 14(10):1045-53. doi: 10.1038/ni.2704

33. Tousoulis D, Oikonomou E, Economou EK, Crea F, Kaski JC. Inflammatory cytokines in atherosclerosis: current therapeutic approaches. Eur Heart $J$ (2016) 37(22):1723-32. doi: 10.1093/eurheartj/ehv759

34. Teixeira V, Tam LS. Novel Insights in Systemic Lupus Erythematosus and Atherosclerosis. Front Med (Lausanne) (2018) 29(4):262. doi: 10.3389/ fmed.2017.00262

35. Diaz-Ricart M, Torramade-Moix S, Pascual G, Palomo M, Moreno-Castano $\mathrm{AB}$, Martinez-Sanchez J, et al. Endothelial Damage, Inflammation and
Immunity in Chronic Kidney Disease. Toxins (Basel) (2020) 12(6):361 doi: $10.3390 /$ toxins 12060361

36. Casciano F, Pigatto PD, Secchiero P, Gambari R, Reali E. T Cell Hierarchy in the Pathogenesis of Psoriasis and Associated Cardiovascular Comorbidities. Front Immunol (2018) 9:1390. doi: 10.3389/fimmu.2018.01390

37. Bortoluzzi A, Chighizola CB, Fredi M, Raschi E, Bodio C, Privitera D, et al. The IMMENSE study: the Interplay between iMMune and ENdothelial cells in mediating cardiovascular risk in Systemic lupus Erythematosus. Front Immunol (2020) 11:572876. doi: 10.3389/fimmu.2020.572876

38. Tedgui A, Mallat Z. Cytokines in atherosclerosis: pathogenic and regulatory pathways. Physiol Rev (2006) 86(2):515-81. doi: 10.1152/physrev. 00024.2005

39. Burnstock G, Boeynaems JM. Purinergic signalling and immune cells. Purinergic Signal (2014) 10(4):529-64. doi: 10.1007/s11302-014-9427-2

40. Burnstock G. Purinergic Signaling in the Cardiovascular System. Circ Res (2017) 120(1):207-28. doi: 10.1161/CIRCRESAHA.116.309726

41. Cekic C, Linden J. Purinergic regulation of the immune system. Nat Rev Immunol (2016) 16(3):177-92. doi: 10.1038/nri.2016.4

42. Antonioli L, Blandizzi C, Pacher P, Hasko G. Immunity, inflammation and cancer: a leading role for adenosine. Nat Rev Cancer (2013) 13(12):842-57. doi: $10.1038 / \mathrm{nrc} 3613$

43. Ferrari D, Gambari R, Idzko M, Muller T, Albanesi C, Pastore S, et al. Purinergic signaling in scarring. FASEB J (2016) 30(1):3-12. doi: 10.1096/ fj. $15-274563$

44. Idzko M, Ferrari D, Riegel AK, Eltzschig HK. Extracellular nucleotide and nucleoside signaling in vascular and blood disease. Blood (2014) 124 (7):1029-37. doi: 10.1182/blood-2013-09-402560

45. Woods LT, Ajit D, Camden JM, Erb L, Weisman GA. Purinergic receptors as potential therapeutic targets in Alzheimer's disease. Neuropharmacology (2016) 104:169-79. doi: 10.1016/j.neuropharm.2015.10.031

46. Allard B, Beavis PA, Darcy PK, Stagg J. Immunosuppressive activities of adenosine in cancer. Curr Opin Pharmacol (2016) 29:7-16. doi: 10.1016/ j.coph.2016.04.001

47. Kanthi YM, Sutton NR, Pinsky DJ. CD39: Interface between vascular thrombosis and inflammation. Curr Atheroscler Rep (2014) 16(7):425. doi: 10.1007/s11883-014-0425-1

48. Hechler B, Gachet C. Purinergic Receptors in Thrombosis and Inflammation. Arterioscler Thromb Vasc Biol (2015) 35(11):2307-15. doi: 10.1161/atvbaha.115.303395

49. Burnstock G. Introduction: P2 receptors. Curr Top Med Chem (2004) 4 (8):793-803. doi: 10.2174/1568026043451014

50. Kawate T. P2X Receptor Activation. Adv Exp Med Biol (2017) 1051:55-69. doi: 10.1007/5584_2017_55

51. Peverini L, Beudez J, Dunning K, Chataigneau T, Grutter T. New Insights Into Permeation of Large Cations Through ATP-Gated P2X Receptors. Front Mol Neurosci (2018) 11:265. doi: 10.3389/fnmol. 2018.00265

52. Allsopp RC, Lalo U, Evans RJ. Lipid raft association and cholesterol sensitivity of P2X1-4 receptors for ATP: chimeras and point mutants identify intracellular amino-terminal residues involved in lipid regulation of P2X1 receptors. J Biol Chem (2010) 285(43):32770-7. doi: 10.1074/ jbc.M110.148940

53. Murrell-Lagnado RD. Regulation of P2X Purinergic Receptor Signaling by Cholesterol. Curr Top Membr (2017) 80:211-32. doi: 10.1016/ bs.ctm.2017.05.004

54. Vial C, Evans RJ. Disruption of lipid rafts inhibits P2X1 receptor-mediated currents and arterial vasoconstriction. J Biol Chem (2005) 280(35):30705-11. doi: $10.1074 /$ jbc.M504256200

55. Ralevic V. P2X receptors in the cardiovascular system and their potential as therapeutic targets in disease. Curr Med Chem (2015) 22(7):851-65. doi: $10.2174 / 0929867321666141215094050$

56. Mccarthy AE, Yoshioka C, Mansoor SE. Full-Length P2X7 Structures Reveal How Palmitoylation Prevents Channel Desensitization. Cell (2019) 179 (3):659-70.e613. doi: 10.1016/j.cell.2019.09.017

57. Coccurello R, Volonte C. P2X7 Receptor in the Management of Energy Homeostasis: Implications for Obesity, Dyslipidemia, and Insulin Resistance. Front Endocrinol (Lausanne) (2020) 11:199. doi: 10.3389/ fendo.2020.00199 
58. Idzko M, Ferrari D, Eltzschig HK. Nucleotide signalling during inflammation. Nature (2014) 509(7500):310-7. doi: 10.1038/nature13085

59. Grassi F. The P2X7 Receptor as Regulator of T Cell Development and Function. Front Immunol (2020) 11:1179. doi: 10.3389/fimmu.2020.01179

60. Lee AH, Ledderose C, Li X, Slubowski CJ, Sueyoshi K, Staudenmaier L, et al. Adenosine Triphosphate Release is Required for Toll-Like Receptor-Induced Monocyte/Macrophage Activation, Inflammasome Signaling, Interleukin-1 $\beta$ Production, and the Host Immune Response to Infection. Crit Care Med (2018) 46(12):e1183-9. doi: $10.1097 / \mathrm{ccm} .0000000000003446$

61. Mugisho OO, Green CR, Kho DT, Zhang J, Graham ES, Acosta ML, et al. The inflammasome pathway is amplified and perpetuated in an autocrine manner through connexin 43 hemichannel mediated ATP release. Biochim Biophys Acta Gen Subj (2018) 1862(3):385-93. doi: 10.1016/j.bbagen. 2017.11.015

62. Xie Q, Shen WW, Zhong J, Huang C, Zhang L, Li J. Lipopolysaccharide/ adenosine triphosphate induces IL-1 $\beta$ and IL-18 secretion through the NLRP3 inflammasome in RAW264.7 murine macrophage cells. Int J Mol Med (2014) 34(1):341-9. doi: 10.3892/ijmm.2014.1755

63. Hoseini Z, Sepahvand F, Rashidi B, Sahebkar A, Masoudifar A, Mirzaei H. NLRP3 inflammasome: Its regulation and involvement in atherosclerosis. J Cell Physiol (2018) 233(3):2116-32. doi: 10.1002/jcp.25930

64. Grebe A, Hoss F, Latz E. NLRP3 Inflammasome and the IL-1 Pathway in Atherosclerosis. Circ Res (2018) 122(12):1722-40. doi: 10.1161/circresaha. 118.311362

65. Kelley N, Jeltema D, Duan Y, He Y. The NLRP3 Inflammasome: An Overview of Mechanisms of Activation and Regulation. Int J Mol Sci (2019) 20(13):3328. doi: 10.3390/ijms20133328

66. Stachon P, Peikert A, Michel NA, Hergeth S, Marchini T, Wolf D, et al. P2Y6 deficiency limits vascular inflammation and atherosclerosis in mice. Arterioscler Thromb Vasc Biol (2014) 34(10):2237-45. doi: 10.1161/ atvbaha.114.303585

67. Jacobson KA, Delicado EG, Gachet C, Kennedy C, Von Kugelgen I, Li B, et al. Update of P2Y receptor pharmacology: IUPHAR Review 27. Br J Pharmacol (2020) 177(11):2413-33. doi: 10.1111/bph.15005

68. Chhatriwala M, Ravi RG, Patel RI, Boyer JL, Jacobson KA, Harden TK. Induction of novel agonist selectivity for the ADP-activated $\mathrm{P} 2 \mathrm{Y} 1$ receptor versus the $\mathrm{ADP}$-activated $\mathrm{P} 2 \mathrm{Y} 12$ and $\mathrm{P} 2 \mathrm{Y} 13$ receptors by conformational constraint of an ADP analog. J Pharmacol Exp Ther (2004) 311(3):1038-43. doi: 10.1124/jpet.104.068650

69. Lazarowski ER, Boucher RC. UTP as an extracellular signaling molecule. News Physiol Sci (2001) 16:1-5. doi: 10.1152/physiologyonline.2001.16.1.1

70. Lohman AW, Billaud M, Isakson BE. Mechanisms of ATP release and signalling in the blood vessel wall. Cardiovasc Res (2012) 95(3):269-80. doi: $10.1093 / \mathrm{cvr} / \mathrm{cvs} 187$

71. Lazarowski ER, Sesma JI, Seminario-Vidal L, Kreda SM. Molecular mechanisms of purine and pyrimidine nucleotide release. Adv Pharmacol (2011) 61:221-61. doi: 10.1016/B978-0-12-385526-8.00008-4

72. Hitzel J, Lee E, Zhang Y, Bibli SI, Li X, Zukunft S, et al. Oxidized phospholipids regulate amino acid metabolism through MTHFD2 to facilitate nucleotide release in endothelial cells. Nat Commun (2018) 9 (1):2292. doi: 10.1038/s41467-018-04602-0

73. Jin H, Ko YS, Park SW, Kim HJ. P2Y(2)R activation by ATP induces oxLDLmediated inflammasome activation through modulation of mitochondrial damage in human endothelial cells. Free Radical Biol Med (2019) 136:10917. doi: 10.1016/j.freeradbiomed.2019.04.004

74. Eun SY, Park SW, Lee JH, Chang KC, Kim HJ. P2Y2R activation by nucleotides released from oxLDL-treated endothelial cells (ECs) mediates the interaction between ECs and immune cells through RAGE expression and reactive oxygen species production. Free Radical Biol Med (2014) 69:157-66. doi: 10.1016/j.freeradbiomed.2014.01.022

75. Hollopeter G, Jantzen HM, Vincent D, Li G, England L, Ramakrishnan V, et al. Identification of the platelet ADP receptor targeted by antithrombotic drugs. Nature (2001) 409(6817):202-7. doi: 10.1038/35051599

76. Chiarito M, Sanz-Sanchez J, Cannata F, Cao D, Sturla M, Panico C, et al. Monotherapy with a P2Y12 inhibitor or aspirin for secondary prevention in patients with established atherosclerosis: a systematic review and metaanalysis. Lancet (London England) (2020) 395(10235):1487-95. doi: 10.1016/ S0140-6736(20)30315-9
77. Platsoucas CD, Lu S, Nwaneshiudu I, Solomides C, Agelan A, Ntaoula N, et al. Abdominal aortic aneurysm is a specific antigen-driven $\mathrm{T}$ cell disease. Ann N Y Acad Sci (2006) 1085:224-35. doi: 10.1196/annals.1383.019

78. Lindeman JH, Abdul-Hussien H, Van Bockel JH, Wolterbeek R, Kleemann R. Clinical trial of doxycycline for matrix metalloproteinase-9 inhibition in patients with an abdominal aneurysm: doxycycline selectively depletes aortic wall neutrophils and cytotoxic T cells. Circulation (2009) 119(16):2209-16. doi: 10.1161/CIRCULATIONAHA.108.806505

79. Zerr M, Hechler B, Freund M, Magnenat S, Lanois I, Cazenave J-P, et al. Major Contribution of the P2Y1 Receptor in Purinergic Regulation of TNF $\alpha$-Induced Vascular Inflammation. Circulation (2011) 123(21):240413. doi: 10.1161/CIRCULATIONAHA.110.002139

80. Hechler B, Freund M, Ravanat C, Magnenat S, Cazenave J-P, Gachet C. Reduced Atherosclerotic Lesions in P2Y1/Apolipoprotein E DoubleKnockout Mice. Circulation (2008) 118(7):754-63. doi: 10.1161/ CIRCULATIONAHA.108.788927

81. Nagase M, Abe J, Takahashi K, Ando J, Hirose S, Fujita T. Genomic organization and regulation of expression of the lectin-like oxidized lowdensity lipoprotein receptor (LOX-1) gene. J Biol Chem (1998) 273 (50):33702-7. doi: 10.1074/jbc.273.50.33702

82. Chen X, Qian S, Hoggatt A, Tang H, Hacker TA, Obukhov AG, et al. Endothelial Cell-Specific Deletion of P2Y2 Receptor Promotes Plaque Stability in Atherosclerosis-Susceptible ApoE-Null Mice. Arterioscler Thromb Vasc Biol (2017) 37(1):75-83. doi: 10.1161/atvbaha.116.308561

83. Riegel AK, Faigle M, Zug S, Rosenberger P, Robaye B, Boeynaems JM, et al. Selective induction of endothelial P2Y6 nucleotide receptor promotes vascular inflammation. Blood (2011) 117(8):2548-55. doi: 10.1182/blood2010-10-313957

84. Bowser JL, Lee JW, Yuan X, Eltzschig HK. The hypoxia-adenosine link during inflammation. J Appl Physiol (1985) (2017) 123(5):1303-20. doi: 10.1152/japplphysiol.00101.2017

85. Lasley RD. Adenosine Receptor-Mediated Cardioprotection-Current Limitations and Future Directions. Front Pharmacol (2018) 9:310. doi: 10.3389/fphar.2018.00310

86. Jacobson KA, Balasubramanian R, Deflorian F, Gao ZG. G protein-coupled adenosine (P1) and P2Y receptors: ligand design and receptor interactions. Purinergic Signal (2012) 8(3):419-36. doi: 10.1007/s11302-012-9294-7

87. Fredholm BB, Ap IJ, Jacobson KA, Linden J, Muller CE. International Union of Basic and Clinical Pharmacology. LXXXI. Nomenclature and classification of adenosine receptors-an update. Pharmacol Rev (2011) 63 (1):1-34. doi: 10.1124/pr.110.003285

88. Alencar AKN, Montes GC, Barreiro EJ, Sudo RT, Zapata-Sudo G. Adenosine Receptors As Drug Targets for Treatment of Pulmonary Arterial Hypertension. Front Pharmacol (2017) 4(8):858. doi: 10.3389/fphar.2017.00858

89. Kim DG, Bynoe MS. A2A Adenosine Receptor Regulates the Human BloodBrain Barrier Permeability. Mol Neurobiol (2015) 52(1):664-78. doi: 10.1007/s12035-014-8879-2

90. Gao X, Qian J, Zheng S, Changyi Y, Zhang J, Ju S, et al. Overcoming the blood-brain barrier for delivering drugs into the brain by using adenosine receptor nanoagonist. ACS Nano (2014) 8(4):3678-89. doi: 10.1021/ nn5003375

91. Muller WA. Transendothelial migration: unifying principles from the endothelial perspective. Immunol Rev (2016) 273(1):61-75. doi: 10.1111/ imr. 12443

92. Bhamidipati CM, Mehta GS, Moehle CW, Meher AK, Su G, Vigneshwar NG, et al. Adenosine $2 \mathrm{~A}$ receptor modulates inflammation and phenotype in experimental abdominal aortic aneurysms. FASEB J (2013) 27(6):2122-31. doi: 10.1096/fj.12-214197

93. Park JG, Jeong SJ, Yu J, Kim G, Jeong LS, Oh GT. LJ-1888, a selective antagonist for the $\mathrm{A} 3$ adenosine receptor, ameliorates the development of atherosclerosis and hypercholesterolemia in apolipoprotein E knock-out mice. BMB Rep (2018) 51(10):520-5. doi: 10.5483/BMBRep.2018.51.10.098

94. Allard B, Longhi MS, Robson SC, Stagg J. The ectonucleotidases CD39 and CD73: Novel checkpoint inhibitor targets. Immunol Rev (2017) 276(1):12144. doi: 10.1111/imr.12528

95. Pinsky DJ, Broekman MJ, Peschon JJ, Stocking KL, Fujita T, Ramasamy R et al. Elucidation of the thromboregulatory role of CD39/ectoapyrase in the ischemic brain. J Clin Invest (2002) 109(8):1031-40. doi: 10.1172/JCI10649 
96. Kohler D, Eckle T, Faigle M, Grenz A, Mittelbronn M, Laucher S, et al. CD39/ ectonucleoside triphosphate diphosphohydrolase 1 provides myocardial protection during cardiac ischemia/reperfusion injury. Circulation (2007) 116(16):1784-94. doi: 10.1161/CIRCULATIONAHA.107.690180

97. Robles RJ, Mukherjee S, Vuerich M, Xie A, Harshe R, Cowan PJ, et al. Modulation of CD39 and exogenous APT102 correct immune dysfunction in experimental colitis and Crohn's disease. J Crohns Colitis (2019) 14 (6):8183-30. doi: 10.1093/ecco-jcc/jjz182

98. Koeppen M, Eckle T, Eltzschig HK. Interplay of hypoxia and A2B adenosine receptors in tissue protection. Adv Pharmacol (2011) 61:145-86. doi: 10.1016/B978-0-12-385526-8.00006-0

99. Pedata F, Dettori I, Coppi E, Melani A, Fusco I, Corradetti R, et al. Purinergic signalling in brain ischemia. Neuropharmacology (2016) 104:105-30. doi: 10.1016/j.neuropharm.2015.11.007

100. Huttinger ZM, Milks MW, Nickoli MS, Aurand WL, Long LC, Wheeler DG, et al. Ectonucleotide triphosphate diphosphohydrolase-1 (CD39) mediates resistance to occlusive arterial thrombus formation after vascular injury in mice. Am J Pathol (2012) 181(1):322-33. doi: 10.1016/j.ajpath.2012.03.024

101. Sutton NR, Bouis D, Mann KM, Rashid IM, Mccubbrey AL, Hyman MC, et al. CD73 Promotes Age-Dependent Accretion of Atherosclerosis. Arterioscler Thromb Vasc Biol (2020) 40(1):61-71. doi: 10.1161/ ATVBAHA.119.313002

102. Covarrubias R, Chepurko E, Reynolds A, Huttinger ZM, Huttinger R, Stanfill K, et al. Role of the CD39/CD73 Purinergic Pathway in Modulating Arterial Thrombosis in Mice. Arterioscler Thromb Vasc Biol (2016) 36(9):1809-20. doi: 10.1161/ATVBAHA.116.307374

103. De Giorgi M, Enjyoji K, Jiang G, Csizmadia E, Mitsuhashi S, Gumina RJ, et al. Complete deletion of $\mathrm{Cd} 39$ is atheroprotective in apolipoprotein Edeficient mice. J Lipid Res (2017) 58(7):1292-305. doi: 10.1194/jlr.M072132

104. Behdad A, Sun X, Khalpey Z, Enjyoji K, Wink M, Wu Y, et al. Vascular smooth muscle cell expression of ectonucleotidase CD39 (ENTPD1) is required for neointimal formation in mice. Purinergic Signal (2009) 5 (3):335-42. doi: 10.1007/s11302-009-9158-y

105. Guns PJ, Hendrickx J, Van Assche T, Fransen P, Bult H. P2Y receptors and atherosclerosis in apolipoprotein E-deficient mice. Br J Pharmacol (2010) 159(2):326-36. doi: 10.1111/j.1476-5381.2009.00497.x

106. Garcia RA, Yan M, Search D, Zhang R, Carson NL, Ryan CS, et al. P2Y6 receptor potentiates pro-inflammatory responses in macrophages and exhibits differential roles in atherosclerotic lesion development. PloS One (2014) 9(10):e111385. doi: 10.1371/journal.pone.0111385

107. Ferrari D, Pizzirani C, Adinolfi E, Lemoli RM, Curti A, Idzko M, et al. The P2X7 receptor: a key player in IL-1 processing and release. J Immunol (2006) 176(7):3877-83. doi: 10.4049/jimmunol.176.7.3877

108. Gulinelli S, Salaro E, Vuerich M, Bozzato D, Pizzirani C, Bolognesi G, et al. IL-18 associates to microvesicles shed from human macrophages by a LPS/ TLR-4 independent mechanism in response to P2X receptor stimulation. Eur J Immunol (2012) 42(12):3334-45. doi: 10.1002/eji.201142268

109. Wewers MD, Sarkar A. P2X(7) receptor and macrophage function. Purinergic Signal (2009) 5(2):189-95. doi: 10.1007/s11302-009-9131-9

110. Qu Y, Dubyak GR. P2X7 receptors regulate multiple types of membrane trafficking responses and non-classical secretion pathways. Purinergic Signal (2009) 5(2):163-73. doi: 10.1007/s11302-009-9132-8

111. Rader DJ. IL-1 and atherosclerosis: a murine twist to an evolving human story. J Clin Invest (2012) 122(1):27-30. doi: 10.1172/JCI61163

112. Kirii H, Niwa T, Yamada Y, Wada H, Saito K, Iwakura Y, et al. Lack of interleukin-1beta decreases the severity of atherosclerosis in ApoE-deficient mice. Arterioscler Thromb Vasc Biol (2003) 23(4):656-60. doi: 10.1161/ 01.ATV.0000064374.15232.C3

113. Lombardi M, Mantione ME, Baccellieri D, Ferrara D, Castellano R, Chiesa R, et al. P2X7 receptor antagonism modulates IL-1beta and MMP9 in human atherosclerotic vessels. Sci Rep (2017) 7(1):4872. doi: 10.1038/s41598-01705137-y

114. Mclaren JE, Ramji DP. Interferon gamma: a master regulator of atherosclerosis. Cytokine Growth Factor Rev (2009) 20(2):125-35. doi: 10.1016/j.cytogfr.2008.11.003

115. Humphreys BD, Dubyak GR. Modulation of P2X7 nucleotide receptor expression by pro- and anti-inflammatory stimuli in THP-1 monocytes. J Leukoc Biol (1998) 64(2):265-73. doi: 10.1002/jlb.64.2.265
116. Pizzirani C, Ferrari D, Chiozzi P, Adinolfi E, Sandona D, Savaglio E, et al. Stimulation of P2 receptors causes release of IL-1beta-loaded microvesicles from human dendritic cells. Blood (2007) 109(9):3856-64. doi: 10.1182/ blood-2005-06-031377

117. Gerdes N, Sukhova GK, Libby P, Reynolds RS, Young JL, Schonbeck U. Expression of interleukin (IL)-18 and functional IL-18 receptor on human vascular endothelial cells, smooth muscle cells, and macrophages: implications for atherogenesis. J Exp Med (2002) 195(2):245-57. doi: $10.1084 /$ jem. 20011022

118. Baldrighi M, Mallat Z, Li X. NLRP3 inflammasome pathways in atherosclerosis. Atherosclerosis (2017) 267:127-38. doi: 10.1016/ j.atherosclerosis.2017.10.027

119. Wang F, Huang L, Peng ZZ, Tang YT, Lu MM, Peng Y, et al. Losartan inhibits LPS + ATP-induced IL-1beta secretion from mouse primary macrophages by suppressing NALP3 inflammasome. Die Pharmazie (2014) 69(9):680-4.

120. Coll RC, Robertson AA, Chae JJ, Higgins SC, Muñoz-Planillo R, Inserra MC, et al. A small-molecule inhibitor of the NLRP3 inflammasome for the treatment of inflammatory diseases. Nat Med (2015) 21(3):248-55. doi: $10.1038 / \mathrm{nm} .3806$

121. Martínez GJ, Celermajer DS, Patel S. The NLRP3 inflammasome and the emerging role of colchicine to inhibit atherosclerosis-associated inflammation. Atherosclerosis (2018) 269:262-71. doi: 10.1016/ j.atherosclerosis.2017.12.027

122. Stachon P, Heidenreich A, Merz J, Hilgendorf I, Wolf D, Willecke F, et al. P2X(7) Deficiency Blocks Lesional Inflammasome Activity and Ameliorates Atherosclerosis in Mice. Circulation (2017) 135(25):2524-33. doi: 10.1161/ circulationaha.117.027400

123. Thomas MR, Storey RF. Effect of P2Y12 inhibitors on inflammation and immunity. Thromb Haemost (2015) 114(3):490-7. doi: 10.1160/TH14-12-1068

124. Li D, Wang Y, Zhang L, Luo X, Li J, Chen X, et al. Roles of purinergic receptor P2Y, G protein-coupled 12 in the development of atherosclerosis in apolipoprotein E-deficient mice. Arterioscler Thromb Vasc Biol (2012) 32(8): e81-9. doi: 10.1161/ATVBAHA.111.239095

125. Johnston LR, La Flamme AC, Larsen PD, Harding SA. Prasugrel inhibits platelet-enhanced pro-inflammatory $\mathrm{CD} 4+\mathrm{T}$ cell responses in humans. Atherosclerosis (2015) 239(1):283-6. doi: 10.1016/j.atherosclerosis.2015.01.006

126. Diehl P, Olivier C, Halscheid C, Helbing T, Bode C, Moser M. Clopidogrel affects leukocyte dependent platelet aggregation by P2Y12 expressing leukocytes. Basic Res Cardiol (2010) 105(3):379-87. doi: 10.1007/s00395009-0073-8

127. Afek A, Kogan E, Maysel-Auslender S, Mor A, Regev E, Rubinstein A, et al. Clopidogrel attenuates atheroma formation and induces a stable plaque phenotype in apolipoprotein E knockout mice. Microvasc Res (2009) 77 (3):364-9. doi: 10.1016/j.mvr.2009.01.009

128. Galkina E, Kadl A, Sanders J, Varughese D, Sarembock IJ, Ley K. Lymphocyte recruitment into the aortic wall before and during development of atherosclerosis is partially L-selectin dependent. $J$ Exp Med (2006) 203(5):1273-82. doi: 10.1084/jem.20052205

129. Labasi JM, Petrushova N, Donovan C, Mccurdy S, Lira P, Payette MM, et al. Absence of the P2X7 receptor alters leukocyte function and attenuates an inflammatory response. J Immunol (2002) 168(12):6436-45. doi: 10.4049/ jimmunol.168.12.6436

130. Jamieson GP, Snook MB, Thurlow PJ, Wiley JS. Extracellular ATP causes of loss of L-selectin from human lymphocytes via occupancy of P2Z purinocepters. J Cell Physiol (1996) 166(3):637-42. doi: 10.1002/(SICI) 1097-4652(199603)166:3<637::AID-JCP19>3.0.CO;2-3

131. Cronstein BN, Naime D, Ostad E. The antiinflammatory mechanism of methotrexate. Increased adenosine release at inflamed sites diminishes leukocyte accumulation in an in vivo model of inflammation. J Clin Invest (1993) 92(6):2675-82. doi: 10.1172/JCI116884

132. Van Duijn J, Van Elsas M, Benne N, Depuydt M, Wezel A, Smeets H, et al. CD39 identifies a microenvironment-specific anti-inflammatory CD8(+) Tcell population in atherosclerotic lesions. Atherosclerosis (2019) 285:71-8. doi: 10.1016/j.atherosclerosis.2019.04.217

133. Chow BJ, Small G, Yam Y, Chen L, Mcpherson R, Achenbach S, et al. Prognostic and therapeutic implications of statin and aspirin therapy in individuals with nonobstructive coronary artery disease: results from the 
CONFIRM (COronary CT Angiography EvaluatioN For Clinical Outcomes: An InteRnational Multicenter registry) registry. Arterioscler Thromb Vasc Biol (2015) 35(4):981-9. doi: 10.1161/ATVBAHA.114.304351

134. Bingham TC, Fisher EA, Parathath S, Reiss AB, Chan ES, Cronstein BN. A2A adenosine receptor stimulation decreases foam cell formation by enhancing ABCA1-dependent cholesterol efflux. J Leukoc Biol (2010) 87(4):683-90. doi: 10.1189/jlb.0709513

135. Barnholt KE, Kota RS, Aung HH, Rutledge JC. Adenosine blocks IFNgamma-induced phosphorylation of STAT1 on serine 727 to reduce macrophage activation. J Immunol (2009) 183(10):6767-77. doi: 10.4049/ jimmunol.0900331

136. Reiss AB, Grossfeld D, Kasselman LJ, Renna HA, Vernice NA, Drewes W, et al. Adenosine and the Cardiovascular System. Am J Cardiovasc Drugs (2019) 19(5):449-64. doi: 10.1007/s40256-019-00345-5

137. Vecchio EA, White PJ, May LT. The adenosine A2B G protein-coupled receptor: Recent advances and therapeutic implications. Pharmacol Ther (2019) 198:20-33. doi: 10.1016/j.pharmthera.2019.01.003

138. Jin Y, Fu J. Novel Insights Into the NLRP 3 Inflammasome in Atherosclerosis. J Am Heart Assoc (2019) 8(12):e012219. doi: 10.1161/jaha.119.012219

139. Ding L, Ma W, Littmann T, Camp R, Shen J. The P2Y(2) nucleotide receptor mediates tissue factor expression in human coronary artery endothelial cells. I Biol Chem (2011) 286(30):27027-38. doi: 10.1074/jbc.M111.235176

140. Zhou M, Wang W, Li Y, Zhang Q, Ji H, Li H, et al. The role of P2Y(6)R in cardiovascular diseases and recent development of P2Y(6)R antagonists. Drug Discovery Today (2020) 25(3):568-73. doi: 10.1016/j.drudis.2019.12.015

141. Deo R, Khera A, Mcguire DK, Murphy SA, Meo Neto Jde P, Morrow DA, et al. Association among plasma levels of monocyte chemoattractant protein-1, traditional cardiovascular risk factors, and subclinical atherosclerosis. J Am Coll Cardiol (2004) 44(9):1812-8. doi: 10.1016/j.jacc.2004.07.047

142. Campwala H, Sexton DW, Crossman DC, Fountain SJ. P2Y 6 receptor inhibition perturbs CCL2-evoked signalling in human monocytic and peripheral blood mononuclear cells. J Cell Sci (2014) 127(Pt 22):4964-73. doi: $10.1242 /$ jcs. 159012

143. Bar I, Guns PJ, Metallo J, Cammarata D, Wilkin F, Boeynams JM, et al. Knockout mice reveal a role for P2Y6 receptor in macrophages, endothelial cells, and vascular smooth muscle cells. Mol Pharmacol (2008) 74(3):777-84. doi: $10.1124 / \mathrm{mol} .108 .046904$
144. Ganbaatar B, Fukuda D, Salim HM, Nishimoto S, Tanaka K, Higashikuni Y, et al. Ticagrelor, a P2Y12 antagonist, attenuates vascular dysfunction and inhibits atherogenesis in apolipoprotein-E-deficient mice. Atherosclerosis (2018) 275:124-32. doi: 10.1016/j.atherosclerosis.2018.05.053

145. Halim H, Pinkaew D, Chunhacha P, Sinthujaroen P, Thiagarajan P, Fujise $\mathrm{K}$. Ticagrelor induces paraoxonase-1 (PON1) and better protects hypercholesterolemic mice against atherosclerosis compared to clopidogrel. PloS One (2019) 14(6):e0218934. doi: 10.1371/journal .pone. 0218934

146. Cochain C, Zernecke A. Protective and pathogenic roles of CD8(+) T cells in atherosclerosis. Basic Res Cardiol (2016) 111(6):71. doi: 10.1007/s00395-0160589-7

147. Edfeldt K, Swedenborg J, Hansson GK, Yan ZQ. Expression of toll-like receptors in human atherosclerotic lesions: a possible pathway for plaque activation. Circulation (2002) 105(10):1158-61. doi: 10.1161/circ. 105.10 .1158

148. Que X, Hung MY, Yeang C, Gonen A, Prohaska TA, Sun X, et al. Oxidized phospholipids are proinflammatory and proatherogenic in hypercholesterolaemic mice. Nature (2018) 558(7709):301-6. doi: 10.1038/ s41586-018-0198-8

149. Ferrari D, Vitiello L, Idzko M, La Sala A. Purinergic signaling in atherosclerosis. Trends Mol Med (2015) 21(3):184-92. doi: 10.1016/ j.molmed.2014.12.008

150. De Jong WH, Borm PJ. Drug delivery and nanoparticles:applications and hazards. Int J Nanomed (2008) 3(2):133-49. doi: 10.2147/ijn.s596

Conflict of Interest: The authors declare that the research was conducted in the absence of any commercial or financial relationships that could be construed as a potential conflict of interest.

Copyright (c) 2021 Ferrari, la Sala, Milani, Celeghini and Casciano. This is an openaccess article distributed under the terms of the Creative Commons Attribution License (CC BY). The use, distribution or reproduction in other forums is permitted, provided the original author(s) and the copyright owner(s) are credited and that the original publication in this journal is cited, in accordance with accepted academic practice. No use, distribution or reproduction is permitted which does not comply with these terms. 